\title{
The Cytoskeleton of the Retinal Pigment Epithelium: from Normal Aging to Age-Related Macular Degeneration
}

\author{
Ioana-Sandra Tarau ${ }^{1,+}$, Andreas Berlin ${ }^{1,+}{ }^{+}$, Christine A. Curcio ${ }^{2} \mathbb{D}$ and Thomas Ach ${ }^{1, *}$ \\ 1 Department of Ophthalmology, University Hospital Würzburg, 97080 Würzburg, Germany \\ 2 Department of Ophthalmology and Visual Sciences, University of Alabama at Birmingham, \\ Birmingham, AL 35249, USA \\ * Correspondence: ach_t@ukw.de \\ + These authors contributed equally to this work and should be considered co-first authors.
}

Received: 3 June 2019; Accepted: 18 July 2019; Published: 22 July 2019

\begin{abstract}
The retinal pigment epithelium (RPE) is a unique epithelium, with major roles which are essential in the visual cycle and homeostasis of the outer retina. The RPE is a monolayer of polygonal and pigmented cells strategically placed between the neuroretina and Bruch membrane, adjacent to the fenestrated capillaries of the choriocapillaris. It shows strong apical (towards photoreceptors) to basal/basolateral (towards Bruch membrane) polarization. Multiple functions are bound to a complex structure of highly organized and polarized intracellular components: the cytoskeleton. A strong connection between the intracellular cytoskeleton and extracellular matrix is indispensable to maintaining the function of the RPE and thus, the photoreceptors. Impairments of these intracellular structures and the regular architecture they maintain often result in a disrupted cytoskeleton, which can be found in many retinal diseases, including age-related macular degeneration (AMD). This review article will give an overview of current knowledge on the molecules and proteins involved in cytoskeleton formation in cells, including RPE and how the cytoskeleton is affected under stress conditions-especially in AMD.
\end{abstract}

Keywords: retinal pigment epithelium; cytoskeleton; aging; age-related macular degeneration; actin; microfilament; microtubules; stress fiber

\section{Introduction}

\section{The Retinal Pigment Epithelium}

The retinal pigment epithelium (RPE) is a cellular monolayer located between the photoreceptor outer segments (apical) and the choroidal vasculature (basal). The RPE's own basal lamina is historically considered to be one of the five layers of the Bruch membrane- the inner wall of the choroid [1]. The RPE has several functions including the transportation of ions, water and metabolic products from the subretinal space to the blood vessels of the choriocapillaris [2]; on the other hand, it also takes up nutritional and metabolic essentials such as fatty acids, retinol and glucose from choriocapillaris and delivers these products to the photoreceptors [3]. It plays a central role in the visual cycle, i.e., re-isomerization from all-trans-retinal to 11-cis-retinal [4]. Another major RPE function is the daily phagocytosis of the shed photoreceptor outer-segment tips and intracellular processing and recycling of their constituents $[5,6]$.

A hallmark of this monolayer is a strong apical to basal polarization, which enables the controlled trafficking of proteins and molecules, nutrients, oxygen, and waste products from and into RPE cells $[7,8]$. This has been shown to be important for the RPE cellular metabolism, as well as maintaining 
outer retina health. RPE cells are able to release molecules and proteins or exocytose material into the sub-RPE space (on the basal aspect, between the basal membrane of the RPE cell and the inner collagenous layer of the Bruch membrane) or into the inter-photoreceptor matrix of the subretinal space (between apical processes of the RPE cells and outer segments of the photoreceptors) [9-14].

Intracellularly, RPE cells accumulate different types of organelles (granules) that are relevant in clinical retinal imaging: lipofuscin and melanolipofuscin granules, as well as melanosomes $[15,16]$. Lipofuscin and melanolipofuscin have autofluorescent features and emit light after blue light excitation. This property has widely been used for in vivo imaging of ocular fundus autofluorescence for more than two decades [17,18]. In addition, intracellular mitochondria exhibit a high reflectivity, which is clinically visible in spectral domain optical coherence tomography (SD-OCT) $[19,20]$.

The macula of the human retina has sub-regions of distinctive photoreceptor composition (all-cone fovea, rod-dominant perifovea) that are expected to impact the structure and function of the underlying RPE [21]. Although a monolayer, the RPE cells of human retina show distinct phenotype differences in relation to their position relative to the fovea-RPE cells at the fovea are smaller in diameter, while intracellular lipofuscin granule deposition favors the perifovea [22]. Also, at the perifovea, the highest number of multinucleated RPE cells exist, while multinucleated RPE cells are nearly absent at the fovea [23]. These differences might represent an adaptation to different needs in direct connection and communication with the overlying photoreceptors, supporting the concept that RPE cells and the overlying photoreceptors form a functional unit to sample visual space [21]. A pre-requisite for RPE polarization is the watertight outer blood-retinal barrier formed by a circumferential belt of RPE junctional complexes [8]. Some important intra- and extracellular structures in maintaining this barrier, and the RPE cell shape and morphology, are proteins and multimolecular complexes directly on RPE cells (tight junction, zonula adherens, desmosomes), within RPE cells (membrane cytoskeleton, membrane proteins), or external to the RPE (extracellular matrix) [24-26].

The purpose of this review is to summarize the composition, cellular localization, and function of RPE cytoskeletal constituents, with a special focus on changes in normal aging and in age-related macular degeneration (AMD).

\section{Cytoskeleton of the Retinal Pigment Epithelium}

The cytoskeleton is one of the most multifaceted and complex structures in biological tissues. In addition to providing a structural scaffold for the cell, it also actively participates in a range of processes such as endocytosis, cell division, intracellular transport, adhesion, motility, force transmission, responding to external forces, and adapting cell shape and cell layer geometry to external and internal factors [27-29]. RPE cells exhibit most of these functions, which emphasizes the importance of the cytoskeleton in maintaining outer retinal homeostasis. As with other cell types, the RPE cytoskeleton (Figure 1A) is comprised of three classic filament types: actin, microtubules, and intermediate filaments (Figure 1B) [30-32]. By forming a distinctively structured, dynamic, and communicating network, the RPE cytoskeleton reacts and adapts to signals-both intra- or extracellularly - by a continuing re-organization of the network.

In the following paragraphs, the major cytoskeleton proteins are explained in more detail. It is worth mentioning here that the knowledge of cytoskeleton composition, involved proteins, and changes in pathological conditions is based on findings in both RPE and mostly non-RPE cells. This is acknowledged whenever appropriate. 


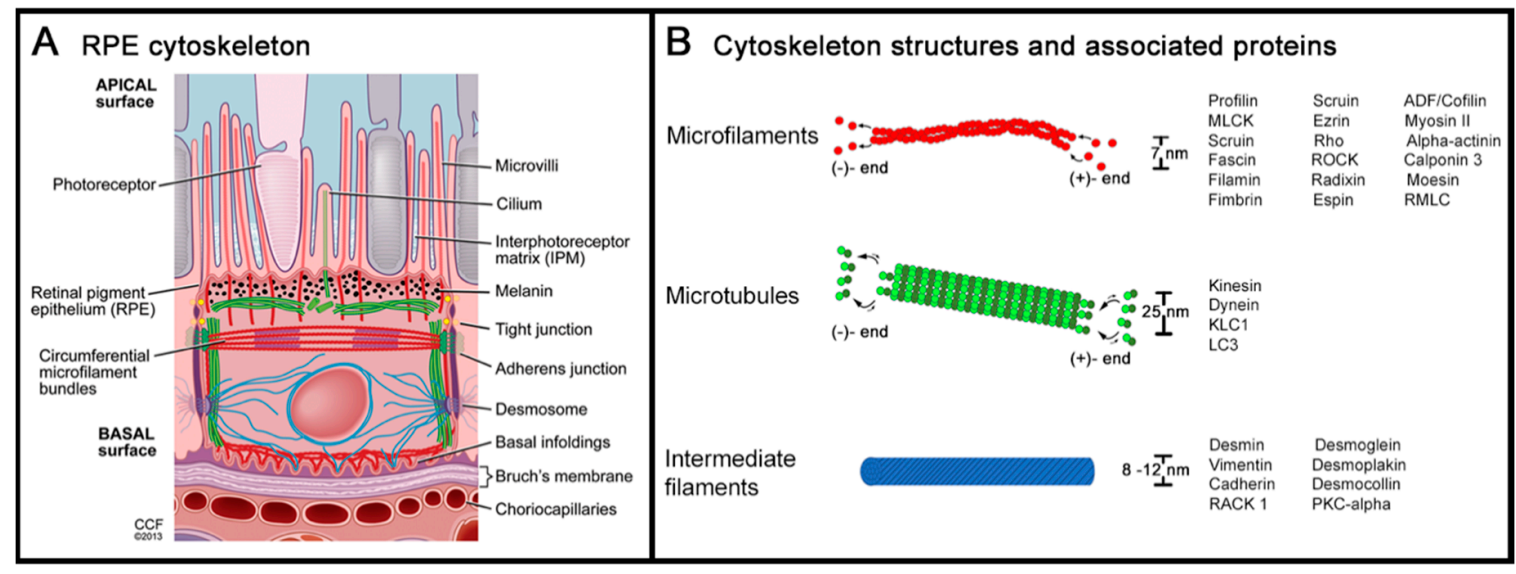

Figure 1. The cytoskeleton of the retinal pigment epithelium (RPE). (A) A cross-sectional view of the RPE and the adjacent photoreceptor outer segments (apical) and Bruch membrane (basal) highlights the intracellular network of cytoskeleton proteins: actin filaments, microtubules, and intermediate filaments. (B) The graph plots the dimension and protein structure of the above-mentioned cytoskeleton members: microfilaments consist of helical arranged polymers of actin proteins with an ATP-rich assembling (+)-end and a less energetic, ADP-rich disassembling (-)-end. Microtubules are hollow cylinders of tubulin proteins, also possessing an energetic, GTP-rich assembling (+)-end and a less energetic GDP-rich disassembling (-)-end. Intermediate filaments form rope-like fibers consisting of a large group of filament-organizing proteins. The regulating and associated proteins of each of the cytoskeleton substructures as mentioned in this review are listed (for details and additional regulating proteins, see detailed reviews from Bonilha and Hohmann et al. [32,33]). Figure 1A: a reprint with permission from Elsevier (via RightsLink) and Vera Bonilha, PhD, and the Cleveland Clinic Center for Medical Art \& Photography [32].

\subsection{Actin and Non-Muscle Myosin}

Actin is a highly dynamic cytoskeletal protein, with a strong ability to adapt to structural changes, thus determining the shape of a cell. Actin microfilaments form a crosslinked grid network of polarized filaments supporting intracellular vesicle trafficking. These microfilaments also interact with several connecting proteins both intracellularly and at the cell border, providing support for focal adhesion, cell shape changes and cell movement [34]. Actin emerges as a branching network with viscoelastic behavior: mainly elastic on shorter time scales ( $<1 \mathrm{~min})$ and more viscous on longer time scales $(>10 \mathrm{~min})[35,36]$. Actin occurs either as monomeric G-actin or filamentous F-actin. In an ATP-dependent reaction, polarized G-actin polymerizes to asymmetric helical structures (= the polarized filamentous actin (F-actin) [37]) with a less dynamic (-)-end and the more dynamic (+)-end [38-41]. Every actin subunit is able to bind ATP and to hydrolyze it to ADP for filament growth, occurring at the (+)-end [42].

Actin polymerization is controlled by several cofactor-driven elements. Profilin, an actin-binding protein, catalyzes the transition from ADP- to ATP-actin and regulates actin formation $[43,44]$. Also, actin closely interacts with the motor-protein myosin [45]. Myosin affects both the retraction of a cell during movement and also transmits forces to the extracellular matrix. However, forces on actin filaments are feasible only when myosin II hexamers have a bipolar filament appearance [46,47]. Myosin activation is regulated by several kinases (inter alia Rho-associated protein kinase, myosin light chain kinases) and phosphorylation of the regulatory light chain or phosphorylation of the myosin heavy chain [48-54].

Myosin belongs to a group of intracellular cross-linker proteins, which connect single actin filaments either transiently/non-transiently and/or passively (e.g., via scruin, fascin, $\alpha$-actinin, filamin, or fimbrin) or actively (myosin). Using ATP as an energy supply, myosin is responsible for the contractility of actin structures [55,56]. The interaction of actin with its cross-linkers largely controls shape, mechanical integrity, and contractility of cells $[29,57,58]$. 
Most actin structures are stable over time. However, to adapt to external environmental factors, cells need a mechanism to induce actin disassembly and re-organization. Therefore, the actin depolymerizing factor (ADF)/cofilin protein family binds to actin and is capable of disassembling and fragmenting actin filaments. ADF/cofilin does not alter the polymerization rate [59,60]. The efficiency of $\mathrm{ADF} /$ cofilin fragmentation highly depends on its binding abundance to actin filaments. Filaments that are fully covered with $\mathrm{ADF} /$ cofilin molecules are stabilized robustly, while actin filaments that are only partially occupied fragment faster $[43,61,62]$. Destabilization and fragmentation of the F-actin cytoskeleton is an observable finding in AMD-affected RPE cells (see below).

\subsection{Microtubules and Intermediate Filaments}

Microtubules consist of polymers originating from $\alpha / \beta$-tubulin heterodimers. These tubularshaped protein complexes have two different polymerization ends (+ and -). Microtubules play an important role in mitosis, cellular growth, cell shape control, and active intracellular transport [63-65] (through kinesin and dynein proteins), facilitated by the microtubule's polarity. GTP-dependent polymerization and depolymerization is also important during mitosis.

In RPE cells, microtubules are involved in the phagocytosis of photoreceptor outer segment tips. Phagosomes use the microtubule network as a guide rail for intracellular travel: maintained by kinesin (plus-end directed), dynein (minus-end directed), and associated proteins (e.g., kinesin-1 light chain 1 (KLC1)). In mice, KLC1 deficiency impairs phagosome translocation in RPE cells and results in AMD-like pathologies [66] including thick basal laminar deposits and deposition of activated complement component C3b. Moreover, the microtubule-associated protein 1 light chain 3 (LC3) family of proteins is essential for maintaining normal lipid homeostasis in RPE-cells. Dhingra et al. recently showed that the systemic deletion of LC3B in mice resulted in an increased phagosome accumulation, a reduced fatty acid oxidation, and intracellular RPE lipid deposition [67]. Furthermore, as demonstrated in non-RPE cells, oxidative stress (also a major contributor to RPE cell disease) affects microtubules and can lead to cytoskeleton re-arrangement [68].

Intermediate filaments are $10 \mathrm{~nm}$ in diameter, i.e., they are intermediate in size between microtubules at $24 \mathrm{~nm}$ and microfilaments at $7 \mathrm{~nm}$. Intermediate filaments are found in the nucleus and cytoplasm and consist of several proteins (neurofilaments, keratins, desmin, vimentin) [69]. This robust intracellular dynamic network is connected to cell-adhesive structures such as desmosomes at cell-cell contacts and hemi-desmosomes at cell-cell or cell-extracellular matrix contacts. The loss of these contacts leads to a loss of adhesion forces between the cells. Intracellularly linked to the actin and microtubule networks, intermediate filaments are responsible for signal transduction from the extracellular to the intracellular space [70] and participate in cell division and cell migration. Intermediate filaments are highly flexible and can be considered "shock absorbers," since they are capable of massive elongation or compression without irreversible damage [71-74].

Under physiological conditions, the intermediate filaments keratin, vimentin, and desmin interact with desmoplakin, a cytolinker associated with desmosomal proteins such as cadherin, desmoglein and desmocollin [69]. Vimentin [75] and actin (among other proteins) are connected to plectin. This interaction decreases mitochondrial motility and elevates the mitochondrial membrane potential. Under stress conditions, phosphorylation of vimentin impacts the vimentin-mitochondria complex and leads to a disassembly of intermediate filaments, with increased motility and reduced ATP production by mitochondria [76,77].

Endocytosis is mediated by the interaction of keratin with the receptor for activated c kinase 1 (RACK1), which controls protein kinase $\mathrm{C} \alpha(\mathrm{PKC} \alpha)$ activity [78]. The alteration of keratin filaments affects endocytosis and impacts intercellular vesicle transport. In addition, an intact keratin network is essential for polarized membrane traffic [79]. All forms of chemical, physical, or mechanical stress impact intermediate filaments and lead to an increased expression of these proteins [80-83]. It is worth mentioning that the RPE's cytoskeleton comprises of keratins (among others, cytokeratin 5, 7, 8, 18, 19), 
with cytokeratin 18 being specific for RPE cells [84]. Cytokeratin 18 can be used as a marker protein in immunostaining and differentiating RPE.

\subsection{Cytoskeleton at the Apical RPE}

Microvilli at the apical surface of RPE cells increase the surface area and closely connect to the photoreceptor's outer segments. Together with microtubules, tightly packed actin filaments within the microvilli help guarantee the structure, polarization, and orientation of apical processes $[85,86]$. Several molecules are important for a normal villi buildup: ezrin, a regulator of actin filaments, and actin-binding proteins such as villin, fimbrin and espin $[87,88]$.

The daily phagocytosis of shed rod and cone photoreceptor outer segment tips requires flexibility, re-arrangement, and the correct orientation of the cytoskeleton [89]. Early studies found that uptake and intracellular processing of extracellular material is mediated by both actin and myosin, as well as microtubules for the fusion of lysosomes and phagosomes [90-93]. Alterations of the actin cytoskeleton and the microtubule system can have a major impact on outer retina health status, leading to a defect in photoreceptor outer-segment uptake and abnormal phagocytosis of the distal membrane stack [94] (of oldest membranes).

The intracellular network of actin and microtubules is also considered important in the transport of pigment granules (melanosomes). Pigment granules within RPE cells move bi-directionally between the apical portion of the cell body and the apical processes $[95,96]$. Numerous melanosomes are found within the apical processes of RPE cells, as first discovered by single-section electron microscopy [97] and recently, quantified by volume electron microscopy [16]. The loss of melanosomes in the apical processes, or the inability of melanosomes to travel into the apical processes, is associated with severe degeneration of RPE cells and the outer retina [98].

Studies localized ezrin [87] and ERM (ezrin, radixin, moesin)-binding phosphoprotein 50 (EBP50) along entire actin filaments of microvilli, implicating this complex as responsible for the dynamics and regulation of microvilli components [99-101]. EBP 50, in direct interaction with the intracellular retinaldehyde binding protein (IRBP) [102-105], is responsible for the transport of hydrophobic retinoids between the RPE and photoreceptors. It also plays a crucial role in retinoid processing and in the visual cycle. The IRBP protein is coded by the gene RBP3 (retinol-binding protein 3, on chromosome 10 in humans [106]). Mutations in or the absence of this gene are associated with retinal diseases including retinitis pigmentosa [107] and retinitis punctata albescens.

\subsection{Cytoskeleton at the Basolateral RPE}

At the basolateral site, the actin filament network is linked to zonula adherens and is responsible for cell-shape. In conjunction with filamin (a binding protein), myosin, tropomyosin (a structural protein), and $\alpha$-actinin (an anchorage protein), actin filaments are part of circumferential microfilament bundles (CMB) which are contractile [108]. In the non-contractile state, tropomyosin and actin have no solid connection. Gunning et al. described a "floating" of the tropomyosin polymer over the surface of the actin filaments, as van der Waals interactions are missing [109]. However, due to mechanical or oxidative stress, these two components become tightly linked [110]. The phosphorylation of regulatory myosin light chain (RMLC) stimulates myosin activity and leads to contractile forces [111], which in turn, are a pre-requisite for the assembly of stress fibers.

The exact molecular pathway of stress fiber formation remains unclear; however, numerous proteins such as calponin 3, Rho-associated coiled-coil kinases (ROCK) and RMLC that maintain stress fiber formation, disassembly, and contractility have been described [112-114]. In general, stress fibers are composed of bundles of multiple actin filaments [115] crosslinked by $\alpha$-actinin [116]. They are connected to intermediate filaments and focal adhesions for signal transduction from the extracellular matrix (ECM) to the intracellular actin cytoskeleton [117-119].

Actin and myosin are two principal constituents of contractile stress fibers and the main contributors to cell contractility in many animal cells [119]. Non-contractile cells do not contain 
myosin [120]. Stress fibers have been well investigated in motile cells, where they can be divided into different categories based on their intracellular location, orientation, and contractility: the perinuclear actin cap, transverse (forming an arc across the top of a cell opposite from its base on a substrate), dorsal (connecting transverse and ventral fibers), and ventral stress fibers (connecting to focal adhesions of the cells to a substrate). Contractility involves the ventral and transverse stress fibers as well as the perinuclear actin cap. Myosin is present along these fibers. Stress fibers also contain actin (which binds proteins and focal adhesion-associated proteins [120-123]), as well as cross-linkers such as $\alpha$-actinin [116], which stabilize the bundle and function as a signaling mediator. Transversal stress fibers form when the dendritic (branching) network collapses and is restructured by myosin [124,125].Ventral stress fibers form from existing dorsal stress fibers, as well as their fusion with attached transverse stress fibers $[120,126]$. The presence of dorsal stress fibers seems to be important for the assembly of the other stress fiber types and a link to focal adhesions [120,121]. Contractile stress fiber types are highly dependent on the presence and activity of myosin. As a result, myosin inhibition leads to the malfunction and degradation of stress fibers [127].

The RPE in its native state has few stress fibers. However, as AMD progresses and cells become dysmorphic, non-epithelioid, and even migratory, the processes described above for motile cells likely become operative [128]. Extracellular deposits (e.g., drusen in AMD, see below) can lead to mechanical stress within RPE cells. Mechanical stress (mechanosensing) is likely not the only trigger for stress fiber formation: thermic and chemical stress have also been discussed.

\subsection{Extracellular Matrix (ECM)}

As mentioned earlier, RPE cells contact and interact with ECM via receptors such as integrins and cadherins $[129,130]$. The basal lamina of RPE cells has historically been considered as part of the 5-layered Bruch membrane (i.e., the basal lamina of the RPE cell, the inner and outer collagenous layer, the elastic fiber band, and the basement membrane of the choriocapillaris). It consists of collagen type IV, fibronectin, hyaluronic acid, and heparan and chondroitin sulfate [131]. Recently, the use of longitudinal eye-tracked clinical spectral domain optical coherence tomography (SD-OCT) has made it possible to appreciate the independent contributions of the RPE basal lamina to AMD progression, as it thickens into the basal laminar deposit $[132,133]$. Thus, an early suggestion that the Bruch membrane is better thought of as a three-layered structure (inner and outer collagenous layers, elastic layer) [134] is garnering a renewed interest [135].

The ECM is a dynamic structure with the ability to adapt to changes in the environment and is also important for cell adhesion and mechanical stability. The ECM also influences the polarity of the adjacent RPE [7]. ECM-RPE cell interactions play a key role in RPE cell adhesion to the Bruch membrane, as well as RPE cell differentiation, morphology, migration, and proliferation [136]. Furthermore, integrins seem to play an important role in the development of neovascular AMD, since altered integrin expression affects the RPE-ECM interaction [137]. Several RPE cell culture systems showed that an altered ECM also affects whole RPE cells, an important finding for the understanding of AMD changes including deposits both in the subretinal space (subretinal drusenoid deposits) and the sub-RPE space (classical soft/hard drusen; see below).

\subsection{RPE Geometry in Normal Aging}

Some of the above-mentioned cytoskeleton properties are necessary for meiosis and cell division. The RPE, however, is believed to be a non-dividing cell monolayer, with little or no signs of cell cycle activity under normal conditions [138]. Therefore, cytoskeleton responsibilities in RPE cells might be different from other cell types.

A seminal 1978 paper by Wing, Blanchard, and Weiter demonstrated the exquisite correlation of lipofuscin-attributable autofluorescence with the topography of photoreceptors in human retina, which was known at the time $[139,140]$. The correlation of foveal cone and RPE topography was shown in horizontal tissue sections by Gao and Hollyfield [141]. Using flatmounts of human retina to produce 
digitally aligned maps of photoreceptors and the RPE [21,22], we demonstrated both a peak in RPE cell numbers under the fovea and the ring of high autofluorescence related to the ring of high rod density in the perifovea and near-periphery. These two studies with accurate foveal centration showed a stability of foveal RPE cell density with aging [22,141]. Ach et al. additionally showed a stability of extrafoveal RPE cell numbers despite an increase of autofluorescence [22].

In normal aging, the RPE monolayer undergoes apparent changes, as recently shown in histological studies of human RPE flatmounts. In persons under 51 years, $>90 \%$ of all RPE cells at the fovea are polygonal with sharp vertices and between 5 and 7 neighbors ( $59 \%$ hexagonal). The proportion of hexagonal cells decreases with increasing distance from the fovea. In advanced age ( $>80$ years), these numbers slightly change with a reduction of hexagonal cells ( $52 \%$ at the fovea), resulting in a more irregular geometry (Figure 2). Interestingly, despite this change in geometry, the overall number of cells remains stable.
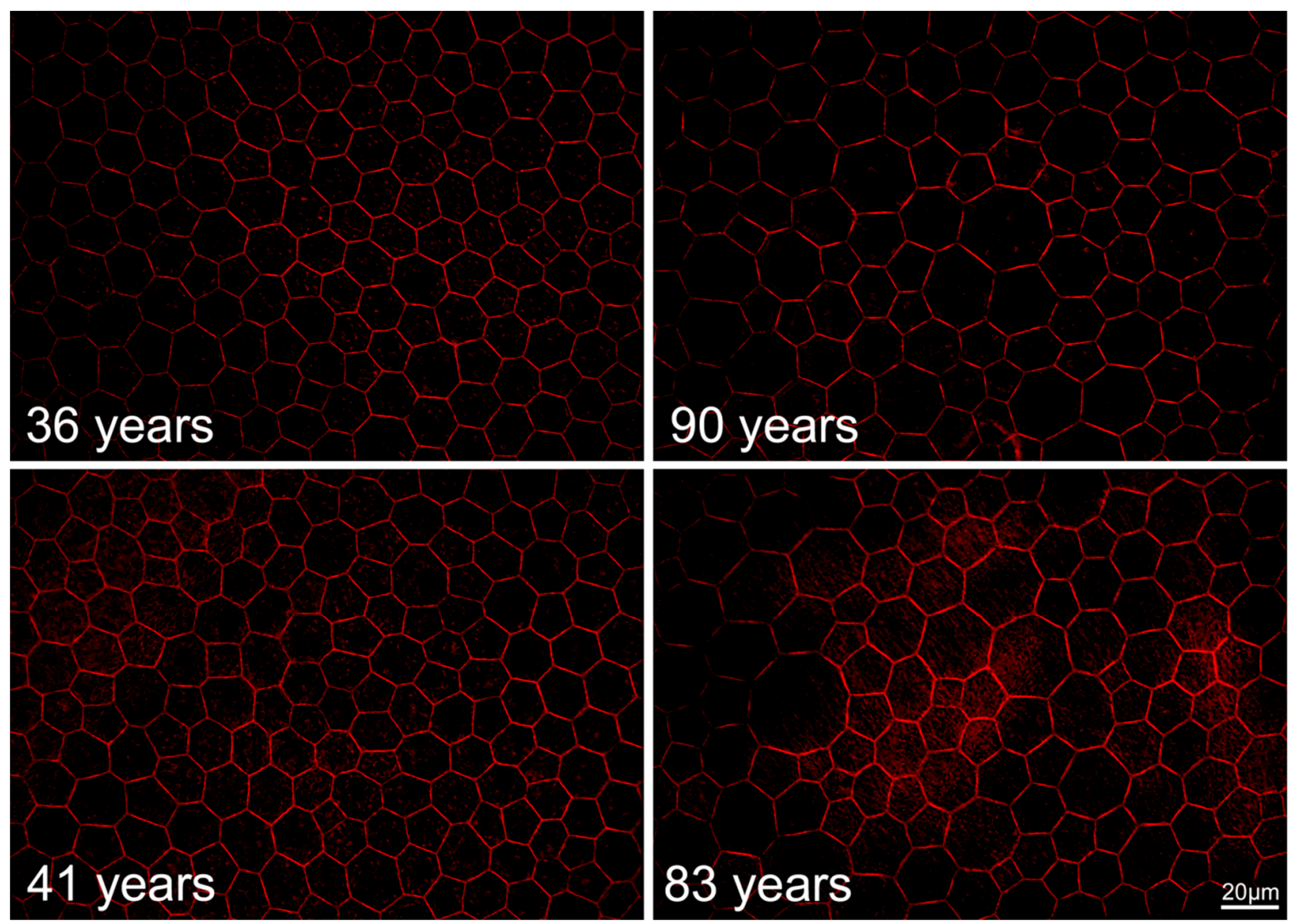

Figure 2. Age-related differences in the RPE cytoskeleton in normal eyes. In young humans (36, 41 years), a uniform geometry of polygonal, mostly hexagonal RPE cells is present, both at the fovea and near periphery. At older ages (83, 90 years) the strict geometry loosens and shows some enlarged cells. This leads to an altered arrangement of the RPE cells. However, orderly packing and a stringent geometry can still be recognized, even at an advanced age. Despite these subtle changes in geometry, the total number of RPE cells at the posterior pole remains stable [22,141,142]. The use of human tissue has previously been approved by the Institutional Review Board at University of Alabama at Birmingham, AL, USA (Protocol X900525013; September 11, 2012.

It is obvious that the RPE cytoskeleton is involved in this re-modeling of the cell layer and that structural changes in the ECM and the surrounding environment might be an initiator for cell layer responses. Age-related changes in the Bruch membrane (including the cross-linking of collagens, the deposition of lipids, increases in thickness, and reductions in elasticity and permeability), as well as basal laminar and basal linear deposits (lipids accumulated between the RPE basal lamina and 
inner collagenous layer of the Bruch membrane), might chemically and mechanically impact the RPE's function and structure.

\subsection{RPE Cytoskeleton in AMD}

In addition to the previously mentioned age-related changes, the RPE cytoskeleton is impacted by several fundamental changes in AMD [143]. The geometry of the monolayer alters significantly at AMD-affected sites (Figures 3 and 4). These areas are patchy and are more likely to be focal than generally distributed across the posterior pole. Also, these areas seem to be associated with subretinal (subretinal drusenoid deposits = reticular pseudodrusen [144]) and sub-RPE-basal lamina deposits (basal linear deposits and drusen). Oxidative stress in RPE cells leads to the release of free radicals. Peroxidized lipoproteins in drusen and basal linear deposits can initiate and promote inflammation, activated complement cascades, and the upregulation of cytokines and chemokines. As mentioned earlier, these factors external to the RPE could trigger cytoskeleton activation [145]. However, despite these subcellular and molecular changes in the surrounding environment of RPE cells, the RPE seems to be able to react and adapt by re-modeling its geometry, while still maintaining function.

Deposits elevate overlying RPE (drusen) or squeeze underlying RPE (subretinal drusenoid deposit), which results in mechanical stress within RPE cells and affects the cytoskeleton. Also, fluid and/or blood (sub RPE, subretinal) in the course of neovascular AMD can significantly mechanically impact retinal architecture and RPE morphology. In vitro studies found that protein expression linked to cell apoptosis (Bcl2, Bax, and p53) was elevated in RPE cells exposed to mechanical stress [146-148]. Continuous mechanical stress can lead to cytoskeleton and RPE phenotype changes [149-152].

Histological studies catalogued 15 different RPE phenotypes associated with non-neovascular and neovascular AMD, with atrophy as the end stage [153,154]. Some phenotypes show a loss of cell contacts and a migration of RPE cells into the neurosensory retina $[155,156]$, where they are seen clinically as hyperreflective foci on SD-OCT. These activities are likely orchestrated by the cell's cytoskeleton as actin filaments are the main contributors to cell migration in terms of force generation and contraction. In cell culture models, different movement modalities have been described (amoeboid versus mesenchymal), with the main differences in adhesion and contractility characteristics [157-159]. Both modalities might be possible for RPE cells in the transition from an epithelial to a mesenchymal phenotype [160]. Still unclear, however, is the initiator for transition and movement: oxygen and nutritional attractant factors in the retina have been discussed, because some cells approach retinal capillaries [155]. Repellent factors in underlying AMD deposits are also a possibility.

At AMD-affected sites, individual RPE cells lose their normal prism shape, enlarge or fuse, and the local spatial density of RPE cells decreases. In general, RPE cells in AMD-affected areas lose their sharp polygonal appearance and become round or even concave [143]. Further cytoskeleton changes in AMD include the thinning and thickening of F-actin, the splitting and fragmentation of F-actin, and the development of stress fibers (Figure 4 summarizes the cytoskeleton findings in AMD). 

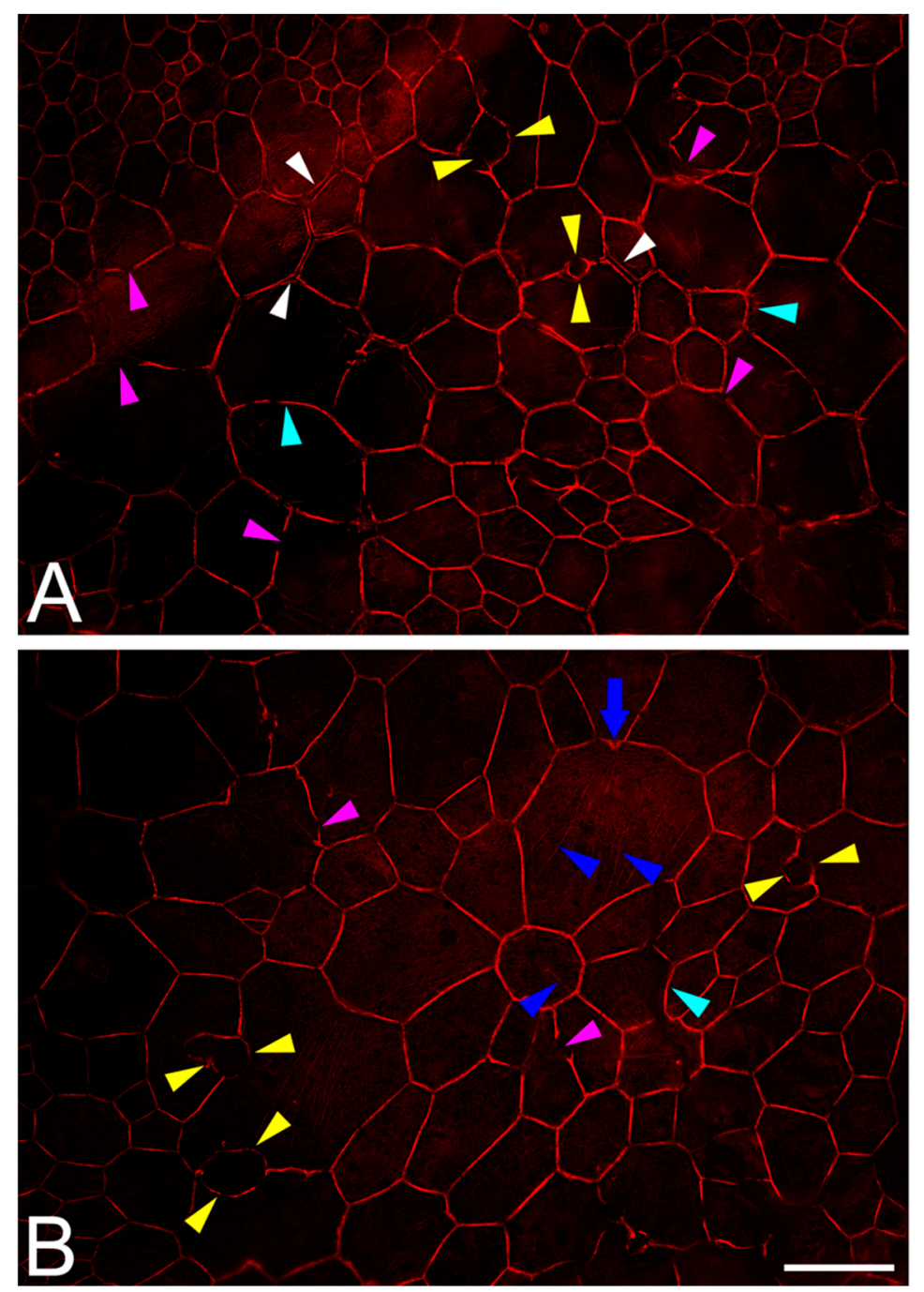

Figure 3. RPE cytoskeleton alterations in age-related macular degeneration (AMD). In contrast to the normal architecture and to age-related changes in RPE geometry (Figure 1), patchy areas with loss of the cells' regular polygonal geometry and shape arise at AMD lesions (A,B). Prima facie, especially enlarged cells with a partly roundish shape (turquoise arrowheads) and variable irregular phenotypes are present. The 'railroad tracks'-like arrangement of adjacent cells' cytoskeleton bands is altered, showing separation (white arrowheads) and fragmentation or interruption (pink arrowheads). A special separation is sporadically seen: a splitting of the cytoskeleton (yellow arrowheads), which starts as small roundish lesions which then enlarge and finally might lead to a complete separation of two cells. A common finding in altered RPE cells is the presence of intracellular stress fibers (in $\mathbf{B}$, blue arrowheads). At the insertion sites of the stress fibers, the actin filament cytoskeleton appears frayed and thickened (blue arrow). Donor: 83 years, female. RPE cells from the parafovea. F-actin labeled with AlexaFluor647-Phalloidin. Scale bar: $50 \mu \mathrm{m}$. 


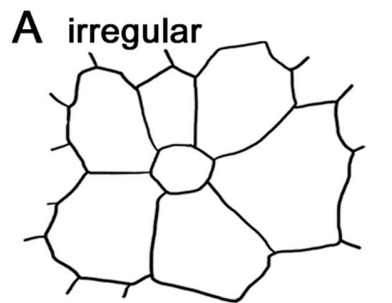

B separated<smiles>CC1CC(C)C(C)C2=C1CCCC2</smiles>
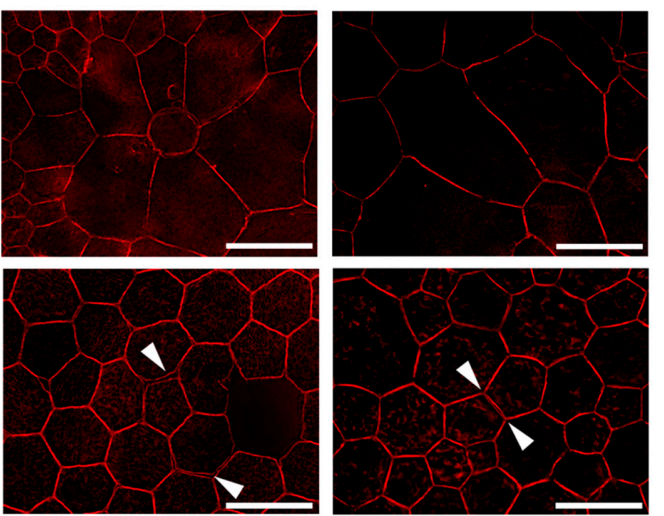

C splitted<smiles>CC1CC2CCCCC2CC1C</smiles>
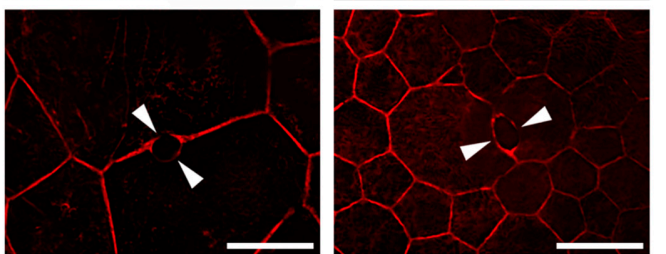

D fragmentated<smiles>CC1CC(C)C2CCCC2C1C</smiles>
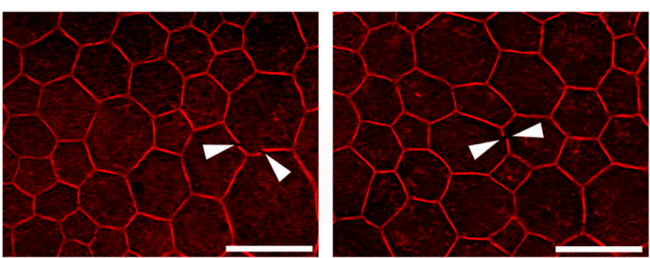

E enlarged \& thinned<smiles>CC1CC(C)CC2CCCCC2CC(C)C1</smiles>
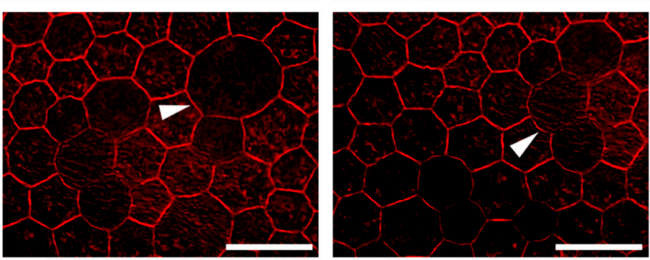

F thickened \& frayed
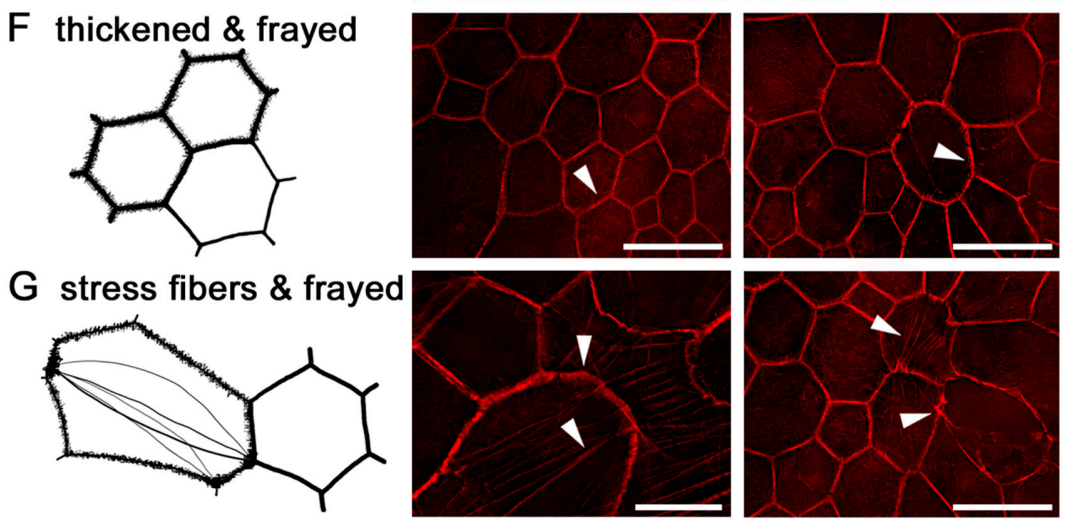

Figure 4. Cytoskeleton changes in AMD-affected eyes. In AMD, RPE cells and the cytoskeleton undergo significant changes. Drawings and photomicrographs show different cells with similar characteristics. (A) The loss of the cytoskeletons' regular polygonal geometry and shape: enlarged cells with partly roundish cell shape and very variable cell sizes. (B) The separation of adjacent cells' cytoskeleton bands. (C) The focal splitting of the cytoskeleton of two adjacent cells. These alterations are tiny in the beginning, but progress over time and can lead to a complete separation of two RPE cells. (D) Cytoskeleton fragmentation with dislocated free ends. Noticeably, the cell shape of these cells appears to be only minimally affected. (E) Enlarged RPE cells with a partly or complete thinned F-actin. (F) A thickened and frayed F-Actin. (G) In affected RPE cells, multiple intracellular stress fibers may appear. At sites where stress fibers insert, the cytoskeleton also appears frayed and thickened. Scale bar: $20 \mu \mathrm{m}$. 
The separation of the cytoskeleton between two adjacent RPE cells may result from mechanical forces from sub-retinal or sub-RPE deposits when cell-to-cell contacts suffer, weaken or disappear under permanent pressure. A similar fragmentation of the F-actin cytoskeleton has been reported in mouse models of different retinopathies or chemically induced RPE degeneration —with basal deposits and a thickened Bruch membrane-as well as in ARPE-19 cell culture models [161,162].

Besides maintaining cell shape and geometry, the cytoskeleton is also involved in the traffic and transport of intracellular granules. Alterations in the cytoskeleton have been linked to poor phagocytosis, as shown in stem-cell-derived RPE cells [163], and might indicate abnormality of other cell functions. An indispensable pre-requisite for any cell replacement therapy is to deliver intact and functioning RPE cells.

As recently shown in a histological survey of $>29,000$ RPE cells [164], a remarkable sign of early AMD in human RPE cells is the re-organization of intracellular autofluorescent lipofuscin granules into aggregates [143], finally leading to a release of these granule aggregates into the sub-RPE space. This re-packing and ejection of granules might be orchestrated by the intracellular cytoskeleton beyond actin, since aggregate-associated changes in actin were not detected in that study.

\section{Conclusions}

The cytoskeleton is an important player in maintaining cell shape and geometry, transmitting signals from the extracellular to the intracellular space (and vice versa), and the intracellular trafficking of granules and proteins. Alterations of the cytoskeleton often result in a change in cell geometry and intracellular trafficking. Age-related changes in the outer retina can be adapted to by the RPE cytoskeleton, while alterations in AMD (splitting, fragmentation, and loss of cytoskeleton) are often accompanied by the occurrence of stress fibers. Because of the importance of polarized pathways for RPE function, these changes to the organizing cytoskeleton will have a major impact on the RPE's ability to care for choriocapillaris and photoreceptors in aging and AMD.

In the future, with the advent of new imaging modalities such as adaptive optics assisted scanning laser ophthalmoscopy, in vivo imaging of individual RPE cells might be available. These techniques enable comprehensive studies on RPE geometry in the aging and diseased eye-and thus, might also serve as an indicator of intracellular RPE cytoskeletal health $[165,166]$.

Funding: The research was funded by NIH 1R01EY027948 (T.A., C.A.C.), 1R01EY06109 (C.A.C.), Dr. Werner Jackstädt Foundation (T.A.). The publication was funded by the German Research Foundation (DFG) and the University of Würzburg in the funding program Open Access Publishing.

Acknowledgments: The authors thank Vera Bonilha, Cleveland Clinic, for providing Figure 1A.

Conflicts of Interest: The authors declare no conflict of interest. The funders had no role in the design of the study; in the collection, analyses, or interpretation of data; in the writing of the manuscript, or in the decision to publish the results.

\section{References}

1. Grierson, I.; Hiscott, P.; Hogg, P.; Robey, H.; Mazure, A.; Larkin, G. Development, repair and regeneration of the retinal pigment epithelium. Eye 1994, 8 Pt 2, 255-262. [CrossRef] [PubMed]

2. Lehmann, G.L.; Benedicto, I.; Philp, N.J.; Rodriguez-Boulan, E. Plasma membrane protein polarity and trafficking in RPE cells: Past, present and future. Exp. Eye Res. 2014, 126, 5-15. [CrossRef] [PubMed]

3. Strauss, O. The Retinal Pigment Epithelium in Visual Function. Physiol. Rev. 2005, 85, 845-881. [CrossRef] [PubMed]

4. Kiser, P.D.; Palczewski, K. Retinoids and Retinal Diseases. Annu. Rev. Vis. Sci. 2016, 2, 197-234. [CrossRef] [PubMed]

5. Kevany, B.M.; Palczewski, K. Phagocytosis of Retinal Rod and Cone Photoreceptors. Physiology 2010, 25, 8-15. [CrossRef] [PubMed]

6. Anderson, D.H.; Fisher, S.K.; Steinberg, R.H. Mammalian cones: Disc shedding, phagocytosis, and renewal. Investig. Ophthalmol. Vis. Sci. 1978, 17, 117-133. 
7. Marmorstein, A.D. The Polarity of the Retinal Pigment Epithelium. Traffic 2001, 2, 867-872. [CrossRef] [PubMed]

8. Rizzolo, L.J. Barrier properties of cultured retinal pigment epithelium. Exp. Eye Res. 2014, 126, 16-26. [CrossRef] [PubMed]

9. Blaauwgeers, H.G.; Holtkamp, G.M.; Rutten, H.; Witmer, A.N.; Koolwijk, P.; Partanen, T.A.; Alitalo, K.; Kroon, M.E.; Kijlstra, A.; van Hinsbergh, V.W. Polarized vascular endothelial growth factor secretion by human retinal pigment epithelium and localization of vascular endothelial growth factor receptors on the inner choriocapillaris: Evidence for a trophic paracrine relation. Am. J. Pathol. 1999, 155, 421-428. [CrossRef]

10. Adamis, A.; Shima, D.; Yeo, K.; Yeo, T.; Brown, L.; Berse, B.; Damore, P.; Folkman, J. Synthesis and Secretion of Vascular Permeability Factor/Vascular Endothelial Growth Factor by Human Retinal Pigment Epithelial Cells. Biochem. Biophys. Res. Commun. 1993, 193, 631-638. [CrossRef] [PubMed]

11. Holtkamp, G.; Kijlstra, A.; Peek, R.; De Vos, A. Retinal Pigment Epithelium-immune System Interactions: Cytokine Production and Cytokine-induced Changes. Prog. Retin. Eye Res. 2001, 20, 29-48. [CrossRef]

12. Wang, A.L.; Lukas, T.J.; Yuan, M.; Du, N.; Tso, M.O.; Neufeld, A.H. Autophagy and Exosomes in the Aged Retinal Pigment Epithelium: Possible Relevance to Drusen Formation and Age-Related Macular Degeneration. PLoS ONE 2009, 4, e4160. [CrossRef]

13. Holtkamp, G.M.; Van Rossem, M.; De Vos, A.F.; Willekens, B.; Peek, R.; Kijlstra, A. Polarized secretion of IL-6 and IL-8 by human retinal pigment epithelial cells. Clin. Exp. Immunol. 1998, 112, 34-43. [CrossRef]

14. Ablonczy, Z.; Dahrouj, M.; Tang, P.H.; Liu, Y.; Sambamurti, K.; Marmorstein, A.D.; Crosson, C.E. Human Retinal Pigment Epithelium Cells as Functional Models for the RPE In Vivo. Investig. Opthalmology Vis. Sci. 2011, 52, 8614-8620. [CrossRef] [PubMed]

15. Feeney, L. Lipofuscin and melanin of human retinal pigment epithelium. Fluorescence, enzyme cytochemical, and ultrastructural studies. Investig. Ophthalmol. Vis. Sci. 1978, 17, 583-600.

16. Pollreisz, A.; Messinger, J.D.; Sloan, K.R.; Mittermueller, T.J.; Weinhandl, A.S.; Benson, E.K.; Kidd, G.J.; Schmidt-Erfurth, U.; Curcio, C.A. Visualizing melanosomes, lipofuscin, and melanolipofuscin in human retinal pigment epithelium using serial block face scanning electron microscopy. Exp. Eye Res. 2018, 166, 131-139. [CrossRef] [PubMed]

17. Delori, F.C.; Dorey, C.K.; Staurenghi, G.; Arend, O.; Goger, D.G.; Weiter, J.J. In vivo fluorescence of the ocular fundus exhibits retinal pigment epithelium lipofuscin characteristics. Investig. Ophthalmol. Vis. Sci. 1995, 36, 718-729.

18. Schmitz-Valckenberg, S.; Holz, F.G.; Bird, A.C.; Spaide, R.F. Fundus autofluorescence imaging: Review and perspectives. Retina 2008, 28, 385-409. [CrossRef] [PubMed]

19. Spaide, R.F.; Curcio, C.A. Anatomical correlates to the bands seen in the outer retina by optical coherence tomography: Literature review and model. Retina 2011, 31, 1609. [CrossRef]

20. Litts, K.M.; Messinger, J.D.; Dellatorre, K.; Yannuzzi, L.A.; Freund, K.B.; Curcio, C.A. Clinicopathological Correlation of Outer Retinal Tubulation in Age-Related Macular Degeneration. JAMA Ophthalmol. 2015, 133, 609. [CrossRef]

21. Curcio, C.A.; Sloan, K.R.; Kalina, R.E.; Hendrickson, A.E. Human photoreceptor topography. J. Comp. Neurol. 1990, 292, 497-523. [CrossRef] [PubMed]

22. Ach, T.; Huisingh, C.; McGwin, G.; Messinger, J.D.; Zhang, T.; Bentley, M.J.; Gutierrez, D.B.; Ablonczy, Z.; Smith, R.T.; Sloan, K.R.; et al. Quantitative Autofluorescence and Cell Density Maps of the Human Retinal Pigment Epithelium. Investig. Opthalmol. Vis. Sci. 2014, 55, 4832-4841. [CrossRef] [PubMed]

23. Starnes, A.C.; Huisingh, C.; McGwin, G.; Sloan, K.R.; Ablonczy, Z.; Smith, R.T.; Curcio, C.A.; Ach, T. Multi-nucleate retinal pigment epithelium cells of the human macula exhibit a characteristic and highly specific distribution. Vis. Neurosci. 2016, 33, E001. [CrossRef] [PubMed]

24. Rizzolo, L.J. Development and Role of Tight Junctions in the Retinal Pigment Epithelium. Adv. Appl. Microbiol. 2007, 258, 195-234.

25. Hudspeth, A.J.; Yee, A.G. The intercellular junctional complexes of retinal pigment epithelia. Investig. Ophthalmol. Vis. Sci. 1973, 12, 354-365.

26. Rizzolo, L.J.; Peng, S.; Luo, Y.; Xiao, W. Integration of tight junctions and claudins with the barrier functions of the retinal pigment epithelium. Prog. Retin. Eye Res. 2011, 30, 296-323. [CrossRef]

27. Stricker, J.; Falzone, T.; Gardel, M.L. Mechanics of the F-actin cytoskeleton. J. Biomech. 2010, 43, 9-14. [CrossRef] 
28. Pollard, T.D.; Cooper, J.A. Actin, a Central Player in Cell Shape and Movement. Science 2009, 326, $1208-1212$. [CrossRef]

29. Fletcher, D.A.; Mullins, R.D. Cell mechanics and the cytoskeleton. Nature 2010, 463, 485-492. [CrossRef]

30. McKechnie, N.M.; Boulton, M.; Robey, H.L.; Savage, F.J.; Grierson, I. The cytoskeletal elements of human retinal pigment epithelium: In vitro and in vivo. J. Cell Sci. 1988, 91, 303-312.

31. Owaribe, K.; Franke, W.W.; Kartenbeck, J.; Rungger-Brändle, E. Cytoskeletons of retinal pigment epithelial cells: Interspecies differences of expression patterns indicate independence of cell function from the specific complement of cytoskeletal proteins. Cell Tissue Res. 1988, 254, 301-315. [CrossRef] [PubMed]

32. Bonilha, V.L. Retinal pigment epithelium (RPE) cytoskeleton in vivo and in vitro. Exp. Eye Res. 2014, 126, 38-45. [CrossRef] [PubMed]

33. Hohmann, T.; Dehghani, F. The Cytoskeleton-A Complex Interacting Meshwork. Cells 2019, 8, 362. [CrossRef] [PubMed]

34. Rotty, J.D.; Bear, J.E. Competition and collaboration between different actin assembly pathways allows for homeostatic control of the actin cytoskeleton. Bioarchitecture 2014, 5, 27-34. [CrossRef] [PubMed]

35. Achard, V.; Martiel, J.-L.; Michelot, A.; Guérin, C.; Reymann, A.-C.; Blanchoin, L.; Boujemaa-Paterski, R. A "Primer"-Based Mechanism Underlies Branched Actin Filament Network Formation and Motility. Curr. Boil. 2010, 20, 423-428. [CrossRef] [PubMed]

36. Kawska, A.; Carvalho, K.; Manzi, J.; Boujemaa-Paterski, R.; Blanchoin, L.; Martiel, J.-L.; Sykes, C. How actin network dynamics control the onset of actin-based motility. Proc. Natl. Acad. Sci. USA 2012, 109, 14440-14445. [CrossRef] [PubMed]

37. Sept, D.; Xu, J.; Pollard, T.D.; McCammon, J.A. Annealing Accounts for the Length of Actin Filaments Formed by Spontaneous Polymerization. Biophys. J. 1999, 77, 2911-2919. [CrossRef]

38. Pollard, T.D. Actin and Actin-Binding Proteins. Cold Spring Harbor Perspect. Biol. 2016, 8. [CrossRef]

39. Bretscher, A.; Weber, K. Villin is a major protein of the microvillus cystoskeleton which binds both $\mathrm{G}$ and $\mathrm{F}$ actin in a calcium-dependent manner. Cell 1980, 20, 839-847. [CrossRef]

40. Vasioukhin, V.; Bauer, C.; Yin, M.; Fuchs, E. Directed Actin Polymerization Is the Driving Force for Epithelial Cell-Cell Adhesion. Cell 2000, 100, 209-219. [CrossRef]

41. Mooseker, M.S.; Kramer, M.F.; Geuze, J.J. Organization of an actin filament-membrane complex. Filament polarity and membrane attachment in the microvilli of intestinal epithelial cells. J. Cell Boil. 1975, 67, 725-743. [CrossRef] [PubMed]

42. Kovar, D.R.; Harris, E.S.; Mahaffy, R.; Higgs, H.N.; Pollard, T.D. Control of the Assembly of ATP- and ADP-Actin by Formins and Profilin. Cell 2006, 124, 423-435. [CrossRef] [PubMed]

43. Andrianantoandro, E.; Pollard, T.D. Mechanism of Actin Filament Turnover by Severing and Nucleation at Different Concentrations of ADF/Cofilin. Mol. Cell 2006, 24, 13-23. [CrossRef] [PubMed]

44. Kang, F.; Purich, D.L.; Southwick, F.S. Profilin Promotes Barbed-end Actin Filament Assembly without Lowering the Critical Concentration. J. Boil. Chem. 1999, 274, 36963-36972. [CrossRef] [PubMed]

45. Adelstein, R.S.; Eisenberg, E. Regulation and Kinetics of the Actin-Myosin-ATP Interaction. Annu. Rev. Biochem. 1980, 49, 921-956. [CrossRef] [PubMed]

46. Finer, J.T.; Simmons, R.M.; Spudich, J.A. Single myosin molecule mechanics: Piconewton forces and nanometre steps. Nature 1994, 368, 113-119. [CrossRef] [PubMed]

47. Mahajan, R.K.; Pardee, J.D. Assembly mechanism of Dictyostelium myosin II: Regulation by $\mathrm{K}+, \mathrm{Mg} 2+$, and actin filaments. Biochemistry 1996, 35, 15504-15514. [CrossRef] [PubMed]

48. Murakami, N.; Chauhan, V.P.S.; Elzinga, M. Two Nonmuscle Myosin II Heavy Chain Isoforms Expressed in Rabbit Brains: Filament Forming Properties, the Effects of Phosphorylation by Protein Kinase C and Casein Kinase II, and Location of the Phosphorylation Sites. Biochemistry 1998, 37, 1989-2003. [CrossRef] [PubMed]

49. Yumura, S.; Yoshida, M.; Betapudi, V.; Licate, L.S.; Iwadate, Y.; Nagasaki, A.; Uyeda, T.Q.; Egelhoff, T.T.; McIntosh, J.R. Multiple Myosin II Heavy Chain Kinases: Roles in Filament Assembly Control and Proper Cytokinesis in Dictyostelium. Mol. Boil. Cell 2005, 16, 4256-4266. [CrossRef]

50. Murakami, N.; Kotula, L.; Hwang, Y.-W. Two Distinct Mechanisms for Regulation of Nonmuscle Myosin Assembly via the Heavy Chain: Phosphorylation for MIIB and Mts 1 Binding for MIIA. Biochemistry 2000, 39, 11441-11451. [CrossRef]

51. Rosenberg, M.; Ravid, S.; Ridley, A. Protein Kinase C $\gamma$ Regulates Myosin IIB Phosphorylation, Cellular Localization, and Filament Assembly. Mol. Boil. Cell 2006, 17, 1364-1374. [CrossRef] [PubMed] 
52. Scholey, J.M.; Taylor, K.A.; Kendrick-Jones, J. Regulation of non-muscle myosin assembly by calmodulin-dependent light chain kinase. Nature 1980, 287, 233-235. [CrossRef] [PubMed]

53. E Kamm, K.; Stull, J.T. The Function of Myosin and Myosin Light Chain Kinase Phosphorylation in Smooth Muscle. Annu. Rev. Pharmacol. Toxicol. 1985, 25, 593-620. [CrossRef] [PubMed]

54. Matsumura, F. Regulation of myosin II during cytokinesis in higher eukaryotes. Trends Cell Boil. 2005, 15, 371-377. [CrossRef] [PubMed]

55. Bendix, P.M.; Koenderink, G.H.; Cuvelier, D.; Dogic, Z.; Koeleman, B.N.; Brieher, W.M.; Field, C.M.; Mahadevan, L.; Weitz, D.A. A Quantitative Analysis of Contractility in Active Cytoskeletal Protein Networks. Biophys. J. 2008, 94, 3126-3136. [CrossRef]

56. Koenderink, G.H.; Dogic, Z.; Nakamura, F.; Bendix, P.M.; MacKintosh, F.C.; Hartwig, J.H.; Stossel, T.P.; Weitz, D.A. An active biopolymer network controlled by molecular motors. Proc. Natl. Acad. Sci. USA 2009, 106, 15192-15197. [CrossRef] [PubMed]

57. Wagner, B.; Tharmann, R.; Haase, I.; Fischer, M.; Bausch, A.R. Cytoskeletal polymer networks: The molecular structure of cross-linkers determines macroscopic properties. Proc. Natl. Acad. Sci. USA 2006, 103, 13974-13978. [CrossRef]

58. Kohler, S.; Schaller, V.; Bausch, A.R. Collective Dynamics of Active Cytoskeletal Networks. PLoS ONE 2011, 6, e23798. [CrossRef]

59. Ingerman, E.; Hsiao, J.Y.; Mullins, R.D. Arp2/3 complex ATP hydrolysis promotes lamellipodial actin network disassembly but is dispensable for assembly. J. Cell Boil. 2013, 200, 619-633. [CrossRef]

60. Reymann, A.-C.; Suarez, C.; Guérin, C.; Martiel, J.-L.; Staiger, C.J.; Blanchoin, L.; Boujemaa-Paterski, R. Turnover of branched actin filament networks by stochastic fragmentation with ADF/cofilin. Mol. Boil. Cell 2011, 22, 2541-2550. [CrossRef]

61. Ngo, K.X.; Kodera, N.; Katayama, E.; Ando, T.; Uyeda, T.Q. Cofilin-induced unidirectional cooperative conformational changes in actin filaments revealed by high-speed atomic force microscopy. eLife 2015, 4. [CrossRef] [PubMed]

62. Elam, W.A.; Kang, H.; De La Cruz, E.M. Biophysics of Actin Filament Severing by Cofilin. FEBS Lett. 2013, 587, 1215-1219. [CrossRef] [PubMed]

63. Brown, R.A.; Talas, G.; Porter, R.A.; McGrouther, D.A.; Eastwood, M. Balanced mechanical forces and microtubule contribution to fibroblast contraction. J. Cell. Physiol. 1996, 169, 439-447. [CrossRef]

64. Rudolph, R.; Woodward, M. Spatial orientation of microtubules in contractile fibroblasts in vivo. Anat. Rec. 1978, 191, 169-181. [CrossRef] [PubMed]

65. Tomasek, J.J. Analysis of the role of microfilaments and microtubules in acquisition of bipolarity and elongation of fibroblasts in hydrated collagen gels. J. Cell Boil. 1984, 99, 536-549. [CrossRef] [PubMed]

66. Jiang, M.; Esteve-Rudd, J.; Lopes, V.S.; Diemer, T.; Lillo, C.; Rump, A.; Williams, D.S. Microtubule motors transport phagosomes in the RPE, and lack of KLC1 leads to AMD-like pathogenesis. J. Cell Boil. 2015, 210, 595-611. [CrossRef] [PubMed]

67. Dhingra, A.; Bell, B.; Peachey, N.S.; Daniele, L.L.; Reyes-Reveles, J.; Sharp, R.C.; Jun, B.; Bazan, N.G.; Sparrow, J.R.; Kim, H.J. Microtubule-Associated Protein 1 light Chain 3B,(LC3B) is Necessary to Maintain Lipid-Mediated Homeostasis in the Retinal Pigment Epithelium. Front. Cell. Neurosci. 2018, 12, 351. [CrossRef]

68. Lee, C.F.; Liu, C.Y.; Hsieh, R.H.; Wei, Y.H. Oxidative stress-induced depolymerization of microtubules and alteration of mitochondrial mass in human cells. Ann. N. Y. Acad. Sci. 2005, 1042, 246-254. [CrossRef]

69. Etienne-Manneville, S. Cytoplasmic Intermediate Filaments in Cell Biology. Annu. Rev. Cell Dev. Boil. 2018, 34, 1-28. [CrossRef]

70. Chang, L.; Goldman, R.D. Intermediate filaments mediate cytoskeletal crosstalk. Nat. Rev. Mol. Cell Boil. 2004, 5, 601-613. [CrossRef]

71. Herrmann, H.; Aebi, U. Intermediate Filaments: Molecular Structure, Assembly Mechanism, and Integration Into Functionally Distinct Intracellular Scaffolds. Annu. Rev. Biochem. 2004, 73, 749-789. [CrossRef] [PubMed]

72. Wang, N.; Stamenović, D. Contribution of intermediate filaments to cell stiffness, stiffening, and growth. Am. J. Physiol. Physiol. 2000, 279, C188-C194. [CrossRef] [PubMed]

73. Godsel, L.M.; Hobbs, R.P.; Green, K.J. Intermediate filament assembly: Dynamics to disease. Trends Cell Boil. 2008, 18, 28-37. [CrossRef] [PubMed] 
74. Sanghvi-Shah, R.; Weber, G.F. Intermediate Filaments at the Junction of Mechanotransduction, Migration, and Development. Front. Cell Dev. Boil. 2017, 5, 81. [CrossRef] [PubMed]

75. Favre, B.; Schneider, Y.; Lingasamy, P.; Bouameur, J.-E.; Begré, N.; Gontier, Y.; Steiner-Champliaud, M.-F.; Frias, M.A.; Borradori, L.; Fontao, L. Plectin interacts with the rod domain of type III intermediate filament proteins desmin and vimentin. Eur. J. Cell Boil. 2011, 90, 390-400. [CrossRef] [PubMed]

76. Sripathi, S.R.; He, W.; Sylvester, O.; Neksumi, M.; Um, J.-Y.; Dluya, T.; Bernstein, P.S.; Jahng, W.J.; Sripathi, S.R. Altered Cytoskeleton as a Mitochondrial Decay Signature in the Retinal Pigment Epithelium. Protein J. 2016, 35, 179-192. [CrossRef]

77. Matveeva, E.A.; Venkova, L.S.; Chernoivanenko, I.S.; Minin, A.A. Vimentin is involved in regulation of mitochondrial motility and membrane potential by Rac1. Boil. Open 2015, 4, 1290-1297. [CrossRef]

78. Kröger, C.; Loschke, F.; Schwarz, N.; Windoffer, R.; Leube, R.E.; Magin, T.M. Keratins control intercellular adhesion involving PKC- $\alpha$-mediated desmoplakin phosphorylation. J. Cell Boil. 2013, 201, 681-692. [CrossRef]

79. Toivola, D.M.; Tao, G.-Z.; Habtezion, A.; Liao, J.; Omary, M.B. Cellular integrity plus: Organelle-related and protein-targeting functions of intermediate filaments. Trends Cell Boil. 2005, 15, 608-617. [CrossRef]

80. Geisler, F.; Leube, R.E. Epithelial Intermediate Filaments: Guardians against Microbial Infection? Cells 2016, 5, 29. [CrossRef]

81. Pekny, M.; Lane, E.B. Intermediate filaments and stress. Exp. Cell Res. 2007, 313, 2244-2254. [CrossRef] [PubMed]

82. Ramms, L.; Fabris, G.; Windoffer, R.; Schwarz, N.; Springer, R.; Zhou, C.; Lazar, J.; Stiefel, S.; Hersch, N.; Schnakenberg, U. Keratins as the main component for the mechanical integrity of keratinocytes. Proc. Natl. Acad. Sci. USA 2013, 110, 18513-18518. [CrossRef] [PubMed]

83. Toivola, D.; Strnad, P.; Habtezion, A.; Omary, M. Intermediate filaments take the heat as stress proteins. Trends Cell Boil. 2010, 20, 79-91. [CrossRef] [PubMed]

84. Fuchs, U.; Kivelä, T.; Tarkkanen, A. Cytoskeleton in normal and reactive human retinal pigment epithelial cells. Investig. Ophthalmol. Vis. Sci. 1991, 32, 3178-3186.

85. Matsumoto, B.; Guérin, C.J.; Anderson, D.H. Cytoskeletal redifferentiation of feline, monkey, and human RPE cells in culture. Investig. Ophthalmol. Vis. Sci. 1990, 31, 879-889.

86. Burnside, B.; Laties, A.M. Actin filaments in apical projections of the primate pigmented epithelial cell. Investig. Ophthalmol. 1976, 15, 570-575.

87. Bretscher, A.; Weber, K. Purification of microvilli and an analysis of the protein components of the microfilament core bundle. Exp. Cell Res. 1978, 116, 397-407. [CrossRef]

88. Gungor-Ordueri, N.E.; Celik-Ozenci, C.; Cheng, C.Y. Ezrin: A regulator of actin microfilaments in cell junctions of the rat testis. Asian J. Androl. 2015, 17, 653-658.

89. Law, A.L.; Parinot, C.; Chatagnon, J.; Gravez, B.; Sahel, J.A.; Bhattacharya, S.S.; Nandrot, E.F. Cleavage of Mer tyrosine kinase (MerTK) from the cell surface contributes to the regulation of retinal phagocytosis. J. Biol. Chem. 2015, 290, 4941-4952. [CrossRef]

90. Stossel, T.P. Phagocytosis. N. Engl. J. Med. 1974, 290, 717-723. [CrossRef]

91. Simson, J.V.; Spicer, S.S. Activities of specific cell constituents in phagocytosis (endocytosis). Int. Rev. Exp. Pathol. 1973, 12, 79-118. [PubMed]

92. Malawista, S.E. Microtubules and the mobilization of lysosomes in phagocytizing human leukocytes. Ann. N. Y. Acad. Sci. 1975, 253, 738-749. [CrossRef] [PubMed]

93. Weissmann, G.; Goldstein, I.; Hoffstein, S.; Tsung, P.-K. Reciprocal effects of camp and cgmp on microtubule-dependent release of lysosomal enzymes. Ann. N. Y. Acad. Sci. 1975, 253, 750-762. [CrossRef] [PubMed]

94. Gibbs, D.; Kitamoto, J.; Williams, D.S. Abnormal phagocytosis by retinal pigmented epithelium that lacks myosin VIIa, the Usher syndrome 1B protein. Proc. Natl. Acad. Sci. USA 2003, 100, 6481-6486. [CrossRef] [PubMed]

95. Barral, D.C.; Seabra, M.C. The Melanosome as a Model to Study Organelle Motility in Mammals. Pigment. Cell Res. 2004, 17, 111-118. [CrossRef] [PubMed]

96. Burgoyne, T.; O'Connor, M.N.; Seabra, M.C.; Cutler, D.F.; Futter, C.E. Regulation of melanosome number, shape and movement in the zebrafish retinal pigment epithelium by OA1 and PMEL. J. Cell Sci. 2015, 128, 1400-1407. [CrossRef] [PubMed] 
97. Steinberg, R.H.; Wood, I.; Hogan, M.J. Pigment Epithelial Ensheathment and Phagocytosis of Extrafoveal Cones in Human Retina. Philos. Trans. R. Soc. B Boil. Sci. 1977, 277, 459-471. [CrossRef]

98. Gibbs, D.; Azarian, S.M.; Lillo, C.; Kitamoto, J.; Klomp, A.E.; Libby, R.T.; Steel, K.P.; Williams, D.S. Role of myosin VIIa and Rab27a in the motility and localization of RPE melanosomes. J. Cell Sci. 2004, 117, 6459-6471. [CrossRef]

99. Bonilha, V.L.; Rodriguez-Boulan, E. Polarity and developmental regulation of two PDZ proteins in the retinal pigment epithelium. Investig. Ophthalmol. Vis. Sci. 2001, 42, 3274-3282.

100. Kivelä, T.; Jääskeläine, J.; Vaheri, A.; Carpén, O. Ezrin, a membrane-organizing protein, as a polarization marker of the retinal pigment epithelium in vertebrates. Cell Tissue Res. 2000, 301, 217-223. [CrossRef]

101. Bonilha, V.L.; Finnemann, S.C.; Rodriguez-Boulan, E. Ezrin Promotes Morphogenesis of Apical Microvilli and Basal Infoldings in Retinal Pigment Epithelium. J. Cell Boil. 1999, 147, 1533-1548. [CrossRef] [PubMed]

102. Nawrot, M.; West, K.; Possin, D.E.; Crabb, J.W.; Huang, J.; Bretscher, A.; Saari, J.C. Cellular Retinaldehyde-Binding Protein Interacts with ERM-Binding Phosphoprotein 50 in Retinal Pigment Epithelium. Investig. Opthalmol. Vis. Sci. 2004, 45, 393-401. [CrossRef] [PubMed]

103. Noa, N. Retinoid-binding proteins: Mediators of retinoid action. Biochem. J. 2000, 348, 481-495. [CrossRef]

104. Gonzalez-Fernandez, F.; Kittredge, K.L.; Rayborn, M.E.; Hollyfield, J.G.; Landers, R.A.; Saha, M.; Grainger, R.M. Interphotoreceptor retinoid-binding protein (IRBP), a major $124 \mathrm{kDa}$ glycoprotein in the interphotoreceptor matrix of Xenopus laevis. Characterization, molecular cloning and biosynthesis. J. Cell Sci. 1993, 105, 7-21. [PubMed]

105. Gonzalez-Fernandez, F.; Ghosh, D. Focus on Molecules: Interphotoreceptor retinoid-binding protein (IRBP). Exp. Eye Res. 2008, 86, 169-170. [CrossRef] [PubMed]

106. Carson, N.; Simpson, N. A physical map of 13 markers on chromosome-10 from dosage studies on abnormal-cell lines. In Cytogenetics and Cell Genetics; Karger: Basel, Switzerlands, 1989; pp. 974-975.

107. Maw, M.A.; Kennedy, B.; Knight, A.; Bridges, R.; Roth, K.E.; Mani, E.; Mukkadan, J.; Nancarrow, D.; Crabb, J.W.; Denton, M.J. Mutation of the gene encoding cellular retinaldehyde-binding protein in autosomal recessive retinitis pigmentosa. Nat. Genet. 1997, 17, 198-200. [CrossRef] [PubMed]

108. Ruiz-Loredo, A.Y.; Lopez-Colome, A.M. New Insights into the Regulation of Myosin Light Chain Phosphorylation in Retinal Pigment Epithelial Cells. In International Review of Cell and Molecular Biology; Elsevier: Amsterdam, The Netherlands, 2012; Volume 293, pp. 85-121.

109. Gunning, P.; O'Neill, G.; Hardeman, E. Tropomyosin-Based Regulation of the Actin Cytoskeleton in Time and Space. Physiol. Rev. 2008, 88, 1-35. [CrossRef] [PubMed]

110. Ciuba, K.; Hawkes, W.; Tojkander, S.; Kogan, K.; Engel, U.; Iskratsch, T.; Lappalainen, P. Calponin-3 is critical for coordinated contractility of actin stress fibers. Sci. Rep. 2018, 8, 17670. [CrossRef]

111. Vicente-Manzanares, M.; Ma, X.; Adelstein, R.S.; Horwitz, A.R. Non-muscle myosin II takes centre stage in cell adhesion and migration. Nat. Rev. Mol. Cell Boil. 2009, 10, 778-790. [CrossRef]

112. Totsukawa, G.; Yamakita, Y.; Yamashiro, S.; Hartshorne, D.J.; Sasaki, Y.; Matsumura, F. Distinct Roles of Rock (Rho-Kinase) and Mlck in Spatial Regulation of Mlc Phosphorylation for Assembly of Stress Fibers and Focal Adhesions in 3t3 Fibroblasts. J. Cell Boil. 2000, 150, 797-806. [CrossRef]

113. Maekawa, M. Signaling from Rho to the Actin Cytoskeleton Through Protein Kinases ROCK and LIM-kinase. Sci. 1999, 285, 895-898. [CrossRef] [PubMed]

114. Tojkander, S.; Gateva, G.; Lappalainen, P. Actin stress fibers-Assembly, dynamics and biological roles. J. Cell Sci. 2012, 125, 1855-1864. [CrossRef] [PubMed]

115. Cramer, L.P. Identification of Novel Graded Polarity Actin Filament Bundles in Locomoting Heart Fibroblasts: Implications for the Generation of Motile Force. J. Cell Boil. 1997, 136, 1287-1305. [CrossRef] [PubMed]

116. Lazarides, E.; Burridge, K. $\alpha$-Actinin: Immunofluorescent localization of a muscle structural protein in nonmuscle cells. Cell 1975, 6, 289-298. [CrossRef]

117. Naumanen, P.; Lappalainen, P.; Hotulainen, P. Mechanisms of actin stress fibre assembly. J. Microsc. 2008, 231, 446-454. [CrossRef] [PubMed]

118. Sjöblom, B.; Salmazo, A.; Djinovic-Carugo, K. $\alpha$-Actinin structure and regulation. Cell. Mol. Life Sci. 2008, 65, 2688-2701. [CrossRef]

119. Koenderink, G.H.; Paluch, E.K. Architecture shapes contractility in actomyosin networks. Curr. Opin. Cell Boil. 2018, 50, 79-85. [CrossRef] 
120. Hotulainen, P.; Lappalainen, P. Stress fibers are generated by two distinct actin assembly mechanisms in motile cells. J. Cell Boil. 2006, 173, 383-394. [CrossRef]

121. Tojkander, S.; Gateva, G.; Schevzov, G.; Hotulainen, P.; Naumanen, P.; Martin, C.; Gunning, P.W.; Lappalainen, P. A Molecular Pathway for Myosin II Recruitment to Stress Fibers. Curr. Boil. 2011, 21, 539-550. [CrossRef]

122. Endlich, N.; Schordan, E.; Cohen, C.D.; Kretzler, M.; Lewko, B.; Welsch, T.; Kriz, W.; Otey, C.A.; Endlich, K. Palladin is a dynamic actin-associated protein in podocytes. Kidney Int. 2009, 75, 214-226. [CrossRef]

123. Schmidt, K.; Nichols, B.J. Functional interdependence between septin and actin cytoskeleton. BMC Cell Boil. 2004, 5, 43 .

124. Burnette, D.T.; Manley, S.; Sengupta, P.; Sougrat, R.; Davidson, M.W.; Kachar, B.; Lippincott-Schwartz, J. A role for actin arcs in the leading-edge advance of migrating cells. Nat. Cell Biol. 2011, 13, 371-382. [CrossRef] [PubMed]

125. Hu, S.; Dasbiswas, K.; Guo, Z.; Tee, Y.-H.; Thiagarajan, V.; Hersen, P.; Chew, T.-L.; Safran, S.A.; Zaidel-Bar, R.; Bershadsky, A.D. Long-range self-organization of cytoskeletal myosin II filament stacks. Nat. Cell Biol. 2017, 19, 133-141. [CrossRef] [PubMed]

126. Tojkander, S.; Gateva, G.; Husain, A.; Krishnan, R.; Lappalainen, P. Generation of contractile actomyosin bundles depends on mechanosensitive actin filament assembly and disassembly. eLife 2015, 4, e06126. [CrossRef] [PubMed]

127. Burridge, K.; Guilluy, C. Focal adhesions, stress fibers and mechanical tension. Exp. Cell Res. 2016, 343, 14-20. [CrossRef]

128. Balaratnasingam, C.; Messinger, J.D.; Sloan, K.R.; Yannuzzi, L.A.; Freund, K.B.; Curcio, C.A. Histology and optical coherence tomographic correlates in drusenoid pigment epithelium detachment in age-related macular degeneration. Ophthalmology 2017, 124, 644-656. [CrossRef] [PubMed]

129. Elner, S.G.; Elner, V.M. The integrin superfamily and the eye. Investig. Ophthalmol. Vis. Sci. 1996, 37, 696-701.

130. Yang, X.; Chung, J.-Y.; Rai, U.; Esumi, N. Cadherins in the retinal pigment epithelium (RPE) revisited: P-cadherin is the highly dominant cadherin expressed in human and mouse RPE in vivo. PLoS ONE 2018, 13, e0191279. [CrossRef]

131. Sorkio, A.; Hongisto, H.; Kaarniranta, K.; Uusitalo, H.; Juuti-Uusitalo, K.; Skottman, H. Structure and Barrier Properties of Human Embryonic Stem Cell-Derived Retinal Pigment Epithelial Cells Are Affected by Extracellular Matrix Protein Coating. Tissue Eng. Part A 2014, 20, 622-634. [CrossRef]

132. Ooto, S.; Vongkulsiri, S.; Sato, T.; Suzuki, M.; Curcio, C.A.; Spaide, R.F. Outer Retinal Corrugations in Age-Related Macular Degeneration. JAMA Ophthalmol. 2014, 132, 806. [CrossRef]

133. Tan, A.C.S.; Astroz, P.; Dansingani, K.K.; Slakter, J.S.; Yannuzzi, L.A.; Curcio, C.A.; Freund, K.B. The Evolution of the Plateau, an Optical Coherence Tomography Signature Seen in Geographic Atrophy. Investig. Opthalmol. Vis. Sci. 2017, 58, 2349. [CrossRef] [PubMed]

134. Bressler, S.B.; Bressler, N.M.; Sarks, S.H.; Sarks, J.P. Age-related macular degeneration: Nonneovascular early AMD, intermediate AMD, and geographic atrophy. In Volume 2: Medical Retina; Elsevier Inc.: Amsterdam, The Netherlands, 2005; pp. 1041-1074.

135. Li, M.; Huisingh, C.; Messinger, J.; Dolz-Marco, R.; Ferrara, D.; Freund, K.B.; Curcio, C.A. Histology of geographic atrophy secondary to age-related macular degeneration: A multilayer approach. Retina 2018, 38, 1937. [CrossRef] [PubMed]

136. Hiscott, P.; Sheridan, C.; Magee, R.M.; Grierson, I. Matrix and the retinal pigment epithelium in proliferative retinal disease. Prog. Retin. Eye Res. 1999, 18, 167-190. [CrossRef]

137. Friedlander, M.; Theesfeld, C.L.; Sugita, M.; Fruttiger, M.; Thomas, M.A.; Chang, S.; Cheresh, D.A. Involvement of integrins alpha v beta 3 and alpha v beta 5 in ocular neovascular diseases. Proc. Natl. Acad. Sci. USA 1996, 93, 9764-9769. [CrossRef] [PubMed]

138. Ts'O, M.O.; Friedman, E. The retinal pigment epithelium. I. Comparative histology. Arch. Ophthalmol. 1967, 78, 641-649. [CrossRef] [PubMed]

139. Østerberg, C. Topography ofthe layer of rods and cones in the human retina. Acta Ophthalmol. 1935, 13, $1-102$.

140. Wing, G.L.; Blanchard, G.C.; Weiter, J.J. The topography and age relationship of lipofuscin concentration in the retinal pigment epithelium. Investig. Ophthalmol. Vis. Sci. 1978, 17, 601-607. 
141. Gao, H.; Hollyfield, J.G. Aging of the human retina. Differential loss of neurons and retinal pigment epithelial cells. Investig. Ophthalmol. Vis. Sci. 1992, 33, 1-17.

142. Del Priore, L.V.; Kuo, Y.-H.; Tezel, T.H. Age-related changes in human RPE cell density and apoptosis proportion in situ. Investig. Ophthalmol. Vis. Sci. 2002, 43, 3312-3318.

143. Ach, T.; Tolstik, E.; Messinger, J.D.; Zarubina, A.V.; Heintzmann, R.; Curcio, C.A. Lipofuscin Redistribution and Loss Accompanied by Cytoskeletal Stress in Retinal Pigment Epithelium of Eyes With Age-Related Macular Degeneration. Investig. Opthalmol. Vis. Sci. 2015, 56, 3242-3252. [CrossRef]

144. Greferath, U.; Guymer, R.H.; Vessey, K.A.; Brassington, K.; Fletcher, E.L. Correlation of Histologic Features with In Vivo Imaging of Reticular Pseudodrusen. Ophthalmology 2016, 123, 1320-1331. [CrossRef] [PubMed]

145. Girouard, M.-P.; Pool, M.; Alchini, R.; Rambaldi, I.; Fournier, A.E. RhoA Proteolysis Regulates the Actin Cytoskeleton in Response to Oxidative Stress. PLoS ONE 2016, 11, 0168641. [CrossRef] [PubMed]

146. Leri, A.; Claudio, P.P.; Li, Q.; Wang, X.; Reiss, K.; Wang, S.; Malhotra, A.; Kajstura, J.; Anversa, P. Stretch-mediated release of angiotensin II induces myocyte apoptosis by activating $\mathrm{p} 53$ that enhances the local renin-angiotensin system and decreases the Bcl-2-to-Bax protein ratio in the cell. J. Clin. Investig. 1998, 101, 1326-1342. [CrossRef] [PubMed]

147. Mazzitello, K.; Zhang, Q.; Chrenek, M.; Family, F.; Grossniklaus, H.; Nickerson, J.; Jiang, Y. Druse-Induced Morphology Evolution in Retinal Pigment Epithelium. arXiv 2016, arXiv:1609.04496 2016.

148. Wu, S.; Lu, Q.; Wang, N.; Zhang, J.; Liu, Q.; Gao, M.; Chen, J.; Liu, W.; Xu, L. Cyclic stretch induced-retinal pigment epithelial cell apoptosis and cytokine changes. BMC Ophthalmol. 2017, 17, 208. [CrossRef] [PubMed]

149. Matthews, B.D.; Overby, D.R.; Mannix, R.; Ingber, D.E. Cellular adaptation to mechanical stress: Role of integrins, Rho, cytoskeletal tension and mechanosensitive ion channels. J. Cell Sci. 2006, 119, 508-518. [CrossRef] [PubMed]

150. Wang, N.; Butler, J.; Ingber, D. Mechanotransduction across the cell surface and through the cytoskeleton. Science 1993, 260, 1124-1127. [CrossRef]

151. Galbraith, C.; Skalak, R.; Chien, S. Shear stress induces spatial reorganization of the endothelial cell cytoskeleton. Cell Motil. Cytoskelet. 1998, 40, 317-330. [CrossRef]

152. Davies, P.F.; Tripathi, S.C. Mechanical stress mechanisms and the cell. An endothelial paradigm. Circ. Res. 1993, 72, 239-245. [CrossRef]

153. Zanzottera, E.C.; Ach, T.; Huisingh, C.; Messinger, J.D.; Spaide, R.F.; Curcio, C.A. Visualizing retinal pigment epithelium phenotypes in the transition to geographic atrophy in age-related macular degeneration. Retina 2016, 36, S12. [CrossRef]

154. Zanzottera, E.C.; Messinger, J.D.; Ach, T.; Smith, R.T.; Freund, K.B.; Curcio, C.A.; Smith, T. The Project MACULA Retinal Pigment Epithelium Grading System for Histology and Optical Coherence Tomography in Age-Related Macular Degeneration. Investig. Opthalmol. Vis. Sci. 2015, 56, 3253-3268. [CrossRef] [PubMed]

155. Curcio, C.A.; Zanzottera, E.C.; Ach, T.; Balaratnasingam, C.; Freund, K.B. Activated retinal pigment epithelium, an optical coherence tomography biomarker for progression in age-related macular degeneration. Investig. Opthalmol. Vis. Sci. 2017, 58, BIO211-BIO226.

156. Zanzottera, E.C.; Messinger, J.D.; Ach, T.; Smith, R.T.; Curcio, C.A. Subducted and Melanotic Cells in Advanced Age-Related Macular Degeneration Are Derived From Retinal Pigment Epithelium. Investig. Opthalmol. Vis. Sci. 2015, 56, 3269-3278. [CrossRef] [PubMed]

157. Parri, M.; Chiarugi, P. Rac and Rho GTPases in cancer cell motility control. Cell Commun. Signal. 2010, 8, 23. [CrossRef] [PubMed]

158. Nguyen, L.K.; Kholodenko, B.N.; Von Kriegsheim, A. Rac1 and RhoA: Networks, loops and bistability. Small GTPases 2018, 9, 316-321. [CrossRef] [PubMed]

159. Friedl, P.; Wolf, K. Plasticity of cell migration: A multiscale tuning model. J. Exp. Med. 2010, 207, 11-19. [CrossRef]

160. Grisanti, S.; Guidry, C. Transdifferentiation of retinal pigment epithelial cells from epithelial to mesenchymal phenotype. Investig. Ophthalmol. Vis. Sci. 1995, 36, 391-405.

161. Ding, J.-D.; Johnson, L.V.; Herrmann, R.; Farsiu, S.; Smith, S.G.; Groelle, M.; Mace, B.E.; Sullivan, P.; Jamison, J.A.; Kelly, U. Anti-amyloid therapy protects against retinal pigmented epithelium damage and vision loss in a model of age-related macular degeneration. Proc. Natl. Acad. Sci. USA 2011, 108, E279-E287. [CrossRef] 
162. Bruban, J.; Glotin, A.-L.; Dinet, V.; Chalour, N.; Sennlaub, F.; Jonet, L.; An, N.; Faussat, A.M.; Mascarelli, F. Amyloid- $\beta(1-42)$ alters structure and function of retinal pigmented epithelial cells. Aging Cell 2009, 8, $162-177$. [CrossRef]

163. Müller, C.; Charniga, C.; Temple, S.; Finnemann, S.C. Quantified F-Actin Morphology Is Predictive of Phagocytic Capacity of Stem Cell-Derived Retinal Pigment Epithelium. Stem Cell Rep. 2018, 10, 1075-1087. [CrossRef]

164. Gambril, J.A.; Sloan, K.R.; Swain, T.A.; Huisingh, C.; Zarubina, A.V.; Messinger, J.D.; Ach, T.; Curcio, C.A. Quantifying Retinal Pigment Epithelium Dysmorphia and Loss of Histologic Autofluorescence in Age-Related Macular Degeneration. Investig. Opthalmol. Vis. Sci. 2019, 60, 2481-2493. [CrossRef] [PubMed]

165. Granger, C.E.; Yang, Q.; Song, H.; Saito, K.; Nozato, K.; Latchney, L.R.; Leonard, B.T.; Chung, M.M.; Williams, D.R.; Rossi, E.A. Human Retinal Pigment Epithelium: In Vivo Cell Morphometry, Multispectral Autofluorescence, and Relationship to Cone Mosaic. Investig. Opthalmol. Vis. Sci. 2018, 59, 5705-5716. [CrossRef] [PubMed]

166. Liu, T.; Jung, H.; Liu, J.; Droettboom, M.; Tam, J. Noninvasive near infrared autofluorescence imaging of retinal pigment epithelial cells in the human retina using adaptive optics. Biomed. Opt. Express 2017, 8, 4348-4360. [CrossRef] [PubMed]

(C) 2019 by the authors. Licensee MDPI, Basel, Switzerland. This article is an open access article distributed under the terms and conditions of the Creative Commons Attribution (CC BY) license (http://creativecommons.org/licenses/by/4.0/). 